\title{
Housing ANd Integration In THE City OF StUtTgaRT, GERMANY
}

\author{
Ayşe Özbabacan
}

\section{$1 \quad$ Migrants in Stuttgart}

The city of Stuttgart is located in the southern Germany and is the capital of the federal state of Baden-Württemberg. Thanks to its immigrants, for many years Stuttgart has maintained its population of 593,000 inhabitants and is today Germany's sixth largest city. Particularly with its automotive and computer industry, Stuttgart represents one of the strongest industrial regions in Germany. Companies such as Daimler, Porsche, Bosch, Hewlett-Packard, IBM and almost 45\% of Baden-Württemberg's research and development capacities have all settled in the Stuttgart region. In addition, the city is one of Germany's top educational locations and is well known as having a very high quality of life. The gross domestic product in 2006 was EUR 35.774 billion. The unemployment rate in June 2009 was a low $6.6 \%$.

Since the mid-1950s Stuttgart has attracted a large number of people from all over the world, in particular "guest workers" (Gastarbeiter) from southern European countries such as Greece, Italy, Spain, Portugal, and Turkey. Soon, however, as early as the 1970s, it became apparent that Stuttgart's migrant workers were not, as previously expected, going to return to their native countries, but were in fact remaining in Stuttgart and bringing their families to live with them. At the end of the 1980s, a new phase of migration history began with the fall of the Iron Curtain. A large number of immigrants from the Eastern European countries came to Germany, among them many ethnic Germans, the so-called Spätaussiedler, but also a large group of persons seeking asylum as well as refugees from the Balkan crisis in the early 1990s. In recent years, Stuttgart's migrants have had more economic than political reasons for migrating to this city.

As in most German cities, the integration of migrants in Stuttgart has taken place primarily by opening up the core institutions, such as the education system and the labour market, and by including the migrants in the welfare system. In addition, a multi-layered system of programs and projects supporting integration was developed over the years. For a long time, however, there has been no wide-ranging integration 
strategy for integrating such "foreigners". Only in the $21^{\text {st }}$ century has Germany introduced a more open citizenship law (2000) and adopted an Immigration Act (2005) ${ }^{16}$ that acknowledges the importance of a comprehensive integration strategy. Moreover, since then two integration summits have been held to address a wide range of integration policy issues including language competency, education and urban planning, with the aim of helping the government develop a comprehensive policy for immigration. The outcome of the Summit culminated in the National Integration Plan (2007) ${ }^{17}$, which included more than 400 measures and voluntary commitments relating to integration developed by the German Government together with the federal states (Länder) and local authorities, associations of migrants, and numerous other non-government players.

\section{Stuttgart Pact for Integration}

Today Stuttgart is a truly international city. Nearly a quarter $(22 \%)$ of the population consists of foreigners (i.e., people without a German passport). The real picture of cultural diversity, however, is even greater, since many immigrants have since been naturalized and are now statistically counted as Germans: Around $40 \%$ of the population has a migration background (people with a non-German citizenship, naturalized Germans, ethnic Germans, and children with at least one parent with migration background $)^{18}$. People come from more than 170 nations and represent 120 linguistic and cultural traditions. Of the foreign population, the Turkish citizens make up the largest migrant group, followed by people from Italy, Greece, Croatia, Serbia and Montenegro and ethnic Germans from the former Soviet Union.

The population with a migration background is constantly increasing. Today more than half of the children living in Stuttgart have a migration background. According to demographic predictions, in the year 2030 this figure will lie at about $50 \%$ of the people living in Stuttgart. This means that Stuttgart will become even more international and more intercultural over the next decade and has to deal with demographic change, lower birth rates, and the overall ageing of the population. This is a challenge but also a chance to adapt to changing circumstances.

Since the turn of the new millennium, the city of Stuttgart has explicitly considered immigration as something normal and desirable for the development of the region. The large percentage of people with a migration background is seen as a benefit and

16 See: http://www.bundesregierung.de/Webs/Breg/DE/Bundesregierung/Beauftragtefuer Integration/Einbuergerung/einbuergerung.html; Zuwanderungskommission 2001.

17 See: http://www.bundesregierung.de/nn_245708/Content/EN/StatischeSeiten/Schwerpunkte/Integration/kasten1-der-nationale-integrationsplan.html

18 Mikrozensus 2005, see: http://www.destatis.de/jetspeed/portal/cms/Sites/destatis/Internet/ DE/Presse /pk/ 2006/Mikrozensus/Pressebroschuere,property=file.pdf 
resource for the city as a whole. Thus, the city committed itself to promoting social and cultural integration, and to assuring equal opportunities to all of its inhabitants in central areas, such as access to education, work, healthcare, housing, political participation, and recreation. Consequently, the municipal integration policy has been reorientated toward a resource approach.

In 2001, the city council adopted a comprehensive integration policy concept in the form of a "Pact for Integration"19 to promote participation and equal opportunities for everyone, peaceful cohabitation and social cohesion, and the capitalisation of cultural diversity to extend competences within the international municipal society. This pact, developed in a top-down process, is a coalition between the public sector (politics and administration), the private sector (special interest groups and businesses), and civil society (associations, sport clubs, community groups, and NGOs). Hence, this coalition consists of partners strongly committed to integration and aligned in network structures. According to the Pact for Integration, integration has to be understood as the active creation of a common basis for mutual understanding and hence as a two-way process. The precondition for this is the ability and the willingness of both the migrant and native population to follow this course. Consequently, the target groups of the municipal integration policy are newly arrived immigrants, longestablished immigrants, as well as the autochthonous population.

Following this approach, Mayor Wolfgang Schuster made integration policy a top priority and established the Department for Integration Policy. The department is directly responsible to the Mayor and has a central coordinating function. It supports and connects municipal and non-municipal bodies that carry out integration and diversity measures in their own rights. The aim is the establishment of integration as a cross-departmental task and responsibility. To support this aim, an International Committee was set up which is charged with counselling the municipal council and the administration concerning all matters of integration and diversity. The committee is made up of 13 members from the municipal council and 12 informed immigrant residents chosen on suggestions made by the Mayor.

To achieve the central goals of the "Pact for Integration", 12 different interrelated fields of action were formulated and are systematically being implemented by integration-promoting strategies and measures organised and offered in cooperation with other municipal bodies such as schools and NGOs (Landeshauptstadt Stuttgart, Stabsabteilung für Integrationspolitik 2007):

1. Support for newly arrived and established migrants

2. Language and education support in pre-school education

3. Equal opportunities in schools and in education

4. Integration in the workplace

5. Putting integration policies at the heart of the city institutions

19 Schuster 2001; see: http://www.stuttgart.de/img/mdb/publ/9509/3813.pdf. 
6. Integration and participation within the neighbourhoods

7. Urban planning and housing policies for integration

8. Intercultural and international orientation

9. Stuttgart Partnership for Safety and Security

10. Inter-religious dialogue

11. Political participation

12. Public awareness

These measures are not only aimed at migrants, but at the German society as well. However, the measures offered to the migrants have to focus on the needs of migrants, cover intercultural and cross-national offers, and in Stuttgart in particular focus on the quality of offers in order to be successful. The intercultural opening of municipal services and the employment of staff with migration background are key tasks to ensure the intercultural competence of the city administration and deal professionally with cultural diversity. Currently, the city is developing a monitoring system focused on measurable outcomes - indicators to gain data on imbalances between migrants and non-migrants.

The Pact found national and international recognition in 2003, when the city was awarded the "Cities for Peace Prize" with honourable mention by the UNESCO. In 2004, the European Council adopted key points of the pact as its official policy on integration. In addition, Stuttgart won the competition for successful integration policies, initiated by the Ministry of the Interior and the Bertelsmann Foundation in 2005 and is now known as a national model of integration policy.

These awards show that the necessary process of integration is a "learning process". Consequently, it is very important to learn from the experiences of other cities and countries in Europe. The city of Stuttgart, together with the European Foundation for the Improvement for Better Living and Working Conditions and the Congress of Local and Regional Authorities of the Council of Europe, in 2006 established the European cities network CLIP "Cities for Local Integration Policies of Migrants". The network aims to bring together European cities in a joint learning process to engage in an exchange of information and experiences concerning the integration and participation of immigrants over several years. The goal is to enable local authorities to learn from each other and to deliver a more effective integration policy for immigrants.

Because housing plays a central role in the overall integration of migrants as a relevant issue of life quality in general, the city participated in the first CLIP module on housing and segregation. This was an opportunity for the city to evaluate the impact of the overall strategy in particular with regard to the housing situation of migrants in Stuttgart. The aim was to invest in urban planning and housing policies to avoid mono-ethnic residential areas and to reduce spatial segregation, that is, promote

20 See: http://www.eurofound.europa.eu/areas/populationandsociety/clip.htm. 
mixed population structures within the neighbourhoods and good living standards for its inhabitants in order to assure social cohesion. ${ }^{21}$

\section{Housing Stock and Housing Market in Stuttgart}

Stuttgart's inner city is located in a basin surrounded by slopes on three sides. They open only toward the river Neckar, in the Northeast. This fact has significant impact on the housing market. Real-estate prices and rents are, because of these topographical restrictions, very high. The best addresses are located nearer the top of the slopes, especially in the South.

Stuttgart currently has about 300,000 residences, $28 \%$ of which are proprietary and $72 \%$ for rental purposes. $14 \%$ of all residences belong to former public utility housing enterprises, $6 \%$ to Stuttgart's housing society SWSG, and $0.3 \%$ is self-owned.

Because of the cramped Stuttgart "bowl", both construction and housing in Stuttgart have traditionally been rather difficult matters. The persistent excess demand and lack of cheap real estate lead to premium prices and considerable effects on the average size of living arrangements. It is more difficult in Stuttgart than in other comparable cities in Germany to gain access to both high-quality and affordable housing.

\subsection{Housing Situation of Residents with a Migration Background}

Few reliable data exist on the housing situation of people with a migration background: The Office of Statistics does not differentiate between nationalities or according to migrant status since migrants are included into the German welfare system. However, some population groups, especially migrants, clearly suffer more than others do from the housing market and high rents.

Compared to Germans, migrants have, on average, less income at their disposal to finance adequate housing. Migrants also more lose their job because of their low educational standards; they live in smaller housing and have less living space per capita at their disposal than non-migrants. Migrants tend to concentrate in districts that are structurally handicapped and characterised, for example, by criminality or poor physical infrastructure, where housing shortages occur or where several households have to share one housing unit. Another indicator was noted in a qualitative survey of adolescents and women with migration background conducted by the University of Stuttgart: The interviewees reported experiencing discrimination and prejudice on the part of the owners regarding access to housing, for example, when a foreign name is given over

21 Bosswick, Heckmann \& Lüken-Klaßen 2007; Lüken-Klaßen 2007; see http://www.stuttgart.de /integrationspolitik. 
the phone, many advertised apartments are suddenly "already let". Discrimination and stigmatisation are especially active in to districts with a negative image.

\subsection{Spatial Concentration of Residents with a Migration Background}

The non-German population is spread across Stuttgart's entire urban area. In the inner city and the outer northern and eastern districts, characterised by industry, the number of citizens without a German passport is higher than the average in the city and well above averages in other districts. The specific districts are Zuffenhausen and Feuerbach in the North and Bad Cannstatt in the Northeast, Wangen and Untertürkheim in the eastern part of the city, and the central districts Mitte, Nord, Süd, and Ost. In these districts one can also find a higher concentration of economically disadvantaged German population groups. Several quarters in districts with a high percentage of foreigners are acutely affected by poverty: An above-average rate of people is on welfare support. Migration-specific segregation and poverty segregation correlate.

If we look at segregation not on the level of city districts, but rather on the smaller scale of the city blocks, a more differentiated picture appears: Mainly in the abovementioned districts are there some city blocks and streets where the share of the foreign population is even higher than $50 \%$, which has negative implications for all other aspects of life. Especially women and adolescents with a migration background spend most of their spare time within their own city quarter and within homogeneous nonGerman networks. These conditions foster problems such as "double semi-lingualism".

However, the ethnic segregation of the proportionately large migrant groups such as Turks, Italians, Greeks, and citizens from former Yugoslavia has fallen since 1980. Hence, the housing locations of the non-German population have slowly spread over the entire urban area. There is presently no concentration of single ethnic groups in Stuttgart, but rather a concentration of migrants of all nationalities similarly distributed throughout the city.

\section{$4 \quad$ Main Policies to Improve Access to Housing for Migrants and to Avoid Segregation}

\subsection{Housing Allowances and Subsidised Public Housing}

In Germany the local housing situation is greatly influenced by national policies. Two public measures exist that aim at supporting those households identified by the government as being most affected by exclusion: The housing allowance is financed by federal and state governments and is paid to low-income households as a top-up payment for the cost of housing to provide decent housing by facilitating access to 
Map 12: Foreigners in Stuttgart's Municipal Districts, 2005

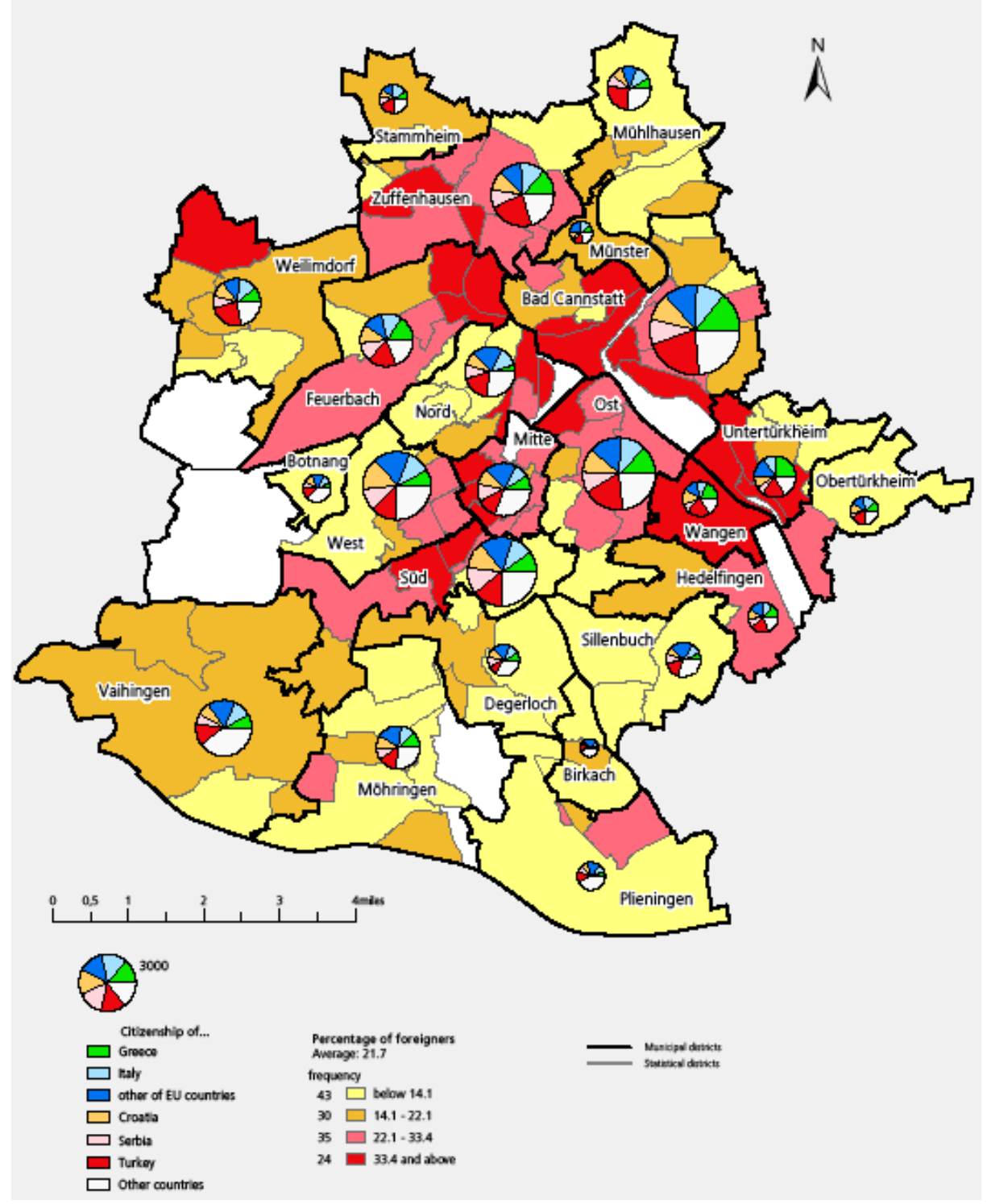

Source: Landeshauptstadt Stuttgart, Statistisches Amt.

accommodation. Whether a household can apply for a housing allowance and how much it can apply for as a subsidy to the rent or mortgage for houseowners depends on the size of the household, the family income, and the rent or costs paid by the appli- 
cants. Because foreigners are included in the German system of welfare, they have the same legal rights to apply for a housing allowance as Germans do, provided they are living legally and permanently in Germany. According to the new Residence Act, permanent residence is generally assumed if the foreigner is given a residence permit valid for more than one year or has held a residence permit for more than 18 months, unless the stay is only of a temporary nature. This means foreign students and seasonal workers could be excluded from public housing, whereas refugees and persons seeking asylum can be lodged in state-owned flats.

The public housing market is regulated by the Housing Assistance Act. This makes the construction of new buildings, the renovation of existing buildings, and the acquisition of occupying rights eligible for public funding. It aims primarily at providing special target groups with proper housing. Households unable, for reasons of income or household size, to supply themselves with appropriate living space are eligible to register at the Office of Housing and Real Estate to receive a place to stay. This procurement requires a housing authorisation permit (Wohnberechtigungsschein), and the applicant has to have lived or worked in Stuttgart for at least 3 years. To cover the demand for such applicants, the office has 17,300 apartments at its disposal, corresponding to $6 \%$ of the entire housing stock in the city. Stuttgart's housing companies receive allocation recommendations for empty apartments from which they may choose future tenants. The waiting period from the time of registration to finally receiving an apartment is generally 6 to 19 months.

In addition, there are several programs to ease the access to the housing market by subsidising the construction of public housing. Social apartment buildings are funded by low-interest loans via the state's living space development program, which itself is funded half and half by the respective state and the federal government. Also, the city supports these buildings by way of price-reduced property, cheap loans and grants, and it subsidises rents for up to 20 years. In this way the city improves the chances for persons with low income, regardless of their background, to get affordable public housing. Neither program is aimed at migrants in particular. Nevertheless, a more relaxed housing market facilitates access to housing for migrants too. For this reason they also indirectly profit from such housing programs, for example, through the Family Building Program, which offers families with children whose income lies below a certain limit funding and low-interest loans when purchasing proprietary housing. Through the program Affordable Proprietary Housing (Preiswertes Wohneigentum), affordable apartments can be built on reduced-price municipal real estate and later sold to families with children. This program is particularly attractive for families with migration background - and is often used by them.

\subsection{Urban Renewal}

Stuttgart is intent on avoiding monoethnic residential areas and segregation. The most important means of preventing this is urban renewal under the auspices of the 
Office of Urban Planning and Renewal. The city invests in the quality of housing facilities, housing areas (including community centres and public areas), and in infrastructure (e.g., schools and public transport) in order to avoid the development of disadvantaged neighbourhoods - and to improve the image of already problematic quarters. Target areas for urban renewal are primarily those areas in which a disproportionate number of underprivileged and inadequately integrated households are situated. Quarters in which a disproportionately large number of migrants live are therefore particularly taken into account.

\subsection{The Urban Development Concept STEK}

From 2004 to 2006, the Office of Urban Planning and Renewal developed the socalled Urban Development Concept (Stadtentwicklungskonzept-STEK) ${ }^{22}$, which introduced 10 goals to act as guidelines for different fields of activity. One of these goals is the "Advancement of Social Cohesion and Integration", based on mutual respect for different cultures and participation of all groups in urban life. To this end the city created several socio-political and infrastructural measures: Besides social projects and projects in schools, certain cultural traditions are also to be considered in housing construction. Preventive measures like the improvement of housing environments (together with the residents) or by offering better recreational and sport activities serve to avoid the formation of social hotspots.

\subsection{The Urban Housing Company SWSG}

A further measure for promoting decent access to housing and reducing segregation is the occupancy policy of the urban housing company SWSG. When assigning their dwellings, the company must meet certain quotas: $80 \%$ of tenants in a housing block should be from the EU, and a maximum of $20 \%$ may be citizens of other countries. This guideline is meant to prevent ethnic segregation and simultaneously promote social mixture. Because $50 \%$ of the rental contracts $(60 \%$ actual tenants) are with non-German citizens (many are Turkish) it is, in practice, nearly impossible for the SWSG to follow this guideline; due to the tenant structure the quotas cannot be fulfilled. Furthermore, although this guideline is meant to prevent ethnic segregation, it does nothing to stop social segregation, which is considered to be significantly more problematic. Hence, the SWSG has established a special department for "Social and Debt Management", which deals with problems in housing. It offers rent debtor counselling to help tenants with financial problems, to prevent evictions, insure the payment of rents, and to establish a new perspective. By way of conflict management and

22 Landeshauptstadt Stuttgart, Amt für Stadtplanung und Stadterneuerung 2004. 
mediation, it tries to improve overall housing satisfaction. A balance of interests among various tenants groups like families with children, senior citizens, or migrants is meant to minimize rent-related conflict. In cases of larger conflicts, roundtable meetings are called. A third field of social work addresses relations with seniors and persons with psychological and physical illness. These people and their relatives should be counselled with respect to the arrangement of their housing situations, and should when necessary be provided with specialised assistance or care.

\subsection{Program "Social City"}

"Social City" (Soziale Stadt) ${ }^{23}$ is a joint federal and state program established in 1999 with the aim of combating the increasing poverty and inequality connected with the emergence of particularly disadvantaged neighbourhoods in German cities. The program areas are selected in accordance with criteria such as unemployment rate, proportion of recipients of social welfare, and of foreigners in a specific neighbourhood. Between 1999 and 2004 the federal government provided more than 400 mio. Euro financial aid. The Social City project is currently being implemented in five neighbourhoods (Rot, Freiberg, Mönchfeld, Fasanenhof, and Hallschlag) in Stuttgart. In these quarters the city follows an integrative approach with the goal of renewing and socially stabilising urban areas, promoting local identity and intercultural integration, and strengthening the local economy. The intent of the project is the enduring renewal and stabilisation of city quarters by combining housing industry and urban construction tasks with social and job market policy effects. The resident community and other local actors are all involved and participate in all projects.

\subsection{House 49}

House 49 is an international neighbourhood centre ${ }^{24}$ with programs and information for the citizens of Stuttgart with various national and ethnic origins. It is sponsored by Caritas, and employs five full-time and various other volunteer workers. Even though it is open to all citizens of Stuttgart, it is used almost exclusively by people with a migration background. The main focus of the neighbourhood centre lies with children and youth services. A nursery school is offered for young children. A daily homework supervision program for some 70 children, including sports and various other activities, is also offered by volunteer workers, in close cooperation with the schools. The program provides meals, holiday camps, excursions, games and other

23 The project is funded by European Social Fund (ESF). See: http://www.sozialestadt.de/programm.

24 See: http://www.haus49.de. 
activities, language instruction, counselling services, and conflict mediation. Through education parties the centre tries to strengthen the involvement and participation of foreign parents in the education and upbringing of their children: In the style of "Tupperware parties" 40 women met monthly for 2 years in order to discuss topics of education and upbringing in an intimate environment. But also sports groups and a Muslim group use premises as well as local seniors for family festivities. With its open and generation-spanning approach it is one of the most often visited international neighbourhood centres in Stuttgart.

\subsection{Security Partnership}

The Stuttgart Police Department and the city of Stuttgart collaborate in a so-called "security partnership" to prevent crime and ensure security in Stuttgart. Based on the assumption that security is not solely a police matter, but one of the community as a whole, the common initiative "Stuttgart Security Partnership" of the police and the citizenry was created in $1997 .^{25}$ The partnership focuses on preventing crime before it occurs. Therefore, security advisory councils as well as specially trained prevention police officers were established in all districts of the city. The partnership carries out various juvenile delinquency programs, such as violence and drug-abuse prevention. Appealing to immigrants and non-German citizens, the partnership assumes that successful crime prevention presumes integration into the host society. The partnership makes a concerted effort to involve Muslim citizens in their prevention activities. In 2005, the partnership succeeded in incorporating representatives of a mosque association into youth services in the Feuerbach district and thus provided them with the opportunity to participate in the development of their own neighbourhood.

\section{Conclusion}

As a relevant issue of life quality in general housing plays a central role in overall integration of immigrants. Housing policies directed at the housing situation of migrants can both affect the structural integration in the receiving society such as labour, education of immigrant children in ethnic concentrations or interethnic interactions, and relations, and are an important part of general social policy at the local level, which has a strong impact on future processes of immigrant integration. Thus, housing is not only an essential sphere of people's everyday life, but also a means for different life chances: Living in a certain district can be associated with one's socio-economic status, image, and local infrastructure. This has an effect on the way people are seen either as integral part of the society or as belonging to segregated areas.

25 See: http://www.stuttgart.de/img/mdb/publ/15134/22585.pdf. 
The integration of foreigners was, until 2001, confined to legal and welfare policies, with little concern for demographic developments or for the socio-spatial dimension of the integration process. However, for some years now, the city of Stuttgart has been aware of the fact that the integration of migrants in particular with regard to housing at the local level is an important factor for the social cohesion of society. Its housing policy aims at mixed population structures within the neighbourhoods and good living standards for its inhabitants in order to ensure social cohesion. Thus, providing a high-quality infrastructure (such as schools, public transportation, and leisure facilities) as well as volunteer work are seen as crucial measures for keeping middleclass families (German and non-German) located as well in disadvantaged neighbourhoods in order to promote a social mix and further integration. Therefore, Stuttgart developed the strategic integration concept Pact for Integration as well as the Urban Development Concept STEK, both of which consider positive inter-group relations among all Stuttgarters and social cohesion as well as socio-spatial integration of migrants to be important goals. In order to achieve these goals, Stuttgart is implementing a multitude of measures and successful projects such as the Social City Program. However, the city lacks solid funding and resources of the municipality to strengthen its integration efforts, that is, to expand and achieve a certain sustainability and institutionalisation of successful projects and thus remove barriers for the further integration of migrants in civic life.

\section{Bibliography}

Bosswick, W., Heckmann, F. \& D. Lüken-Klaßen (2007), Housing and Integration of Migrants in Europe. Dublin: European Foudation for the Improvement of Working and Living Conditions.

Bosswick, W., Borkert, M., Heckmann, F. \& D. Lüken-Klaßen (2007), Local integration policies for migrants in Europe. Dublin.

Landeshauptstadt Stuttgart, Amt für Stadtplanung und Stadterneuerung (2004), Stadtentwicklungskonzept - Strategie 2006. Stuttgart

Landeshauptstadt Stuttgart, Stabsabteilung für Integrationspolitik (2007), Stuttgarter Bündnis für Integration. Weiterentwicklung 2007. Stuttgart.

Lüken-Klaßen, D. (2007), Case Study on Housing, Stuttgart. Dublin: European Foudation for the Improvement of Working and Living Conditions.

Schuster, W. (2001), Stuttgart Pact for Integration. Stuttgart.

Zuwanderungskommission (2001), Zuwanderung gestalten, Integration fördern, Bericht der Unabhängigen Kommission “Zuwanderung”. Berlin.

\section{Web Sources}

http://www.bamf.de/cln_101/nn_1034446/EN/Migration 
http://www.bundesregierung.de/nn_245708/Content/EN/StatischeSeiten/Schwerpunkte/Integrat ion/kasten1-der-nationale-integrationsplan.html

http://www.bundesregierung.de/Webs/Breg/DE/Bundesregierung/BeauftragtefuerIntegration/be auftragte-fuer-integration.html

http://www.destatis.de/jetspeed/portal/cms/Sites/destatis/Internet/DE/Presse/pk/2006/Mikrozen sus/Pressebroschuere,property=file.pdf

http://www.eurofound.europa.eu/areas/populationandsociety/clip.htm

http://www.haus49.de/

http://www.sozialestadt.de/programm/

http://www.stuttgart.de/integrationspolitik

http://www.stuttgart.de/img/mdb/publ/15134/22585.pdf 
